\title{
Karlovy Vary 98
}

\author{
By Ron Holloway
}

Fall 1998 Issue of KINEMA

Moscow's loss was Karlovy Vary's gain. Why wasn't there a Moscow festival this year? Several reasons were given when the news broke at Cannes in May, none of them very promising for the future of the festival. Still, the Russian film industry is well on its way to recovery if the grabbag of features, documentaries, and short films programmed in different sections at the 33rd Karlovy Vary International Film Festival (3-11 July 1998) are to be taken at face value.

For example, Karen Shakhnazarov's Full Moon probably would have opened the Moscow festival instead of premiering as the official Russian entry at Karlovy Vary. Produced by Mosfilm's managing director Vladimir Dostal, this rambling, intertwined, impressionistic tour of Moscow on a summer day from dawn to dusk is packed with a subtle run of sight and verbal gags. It opens with a scene shot on the very premises of the Mosfilm Studios: an out-of-work actor pays a visit to a production office to ask if there might be a part for him in a new film -- that is, if a producer there can finally come up with an idea to make one! Full Moon was awarded the Special Jury Prize at Karlovy Vary.

Another Russian entry more appropriate for a Russian festival than a Czech one was Vladimir Bortko's The Circus Burned Down, the Clowns Are Gone, produced at the Lenfilm Studios and programmed in the "East of the West" section reserved for productions from ex-socialist filmlands. This honest, detailed, bittersweet portrait of a once famous Lenfilm director, now on the verge of financial ruin and psychological collapse, features a unique sequence in contemporary Russian cinema: the depiction of extravagant funeral rites for a murdered banker, replete with a military guard-of-honour, a ballerina troupe dancing around the bier, and, to top it all off, a video résumé of the dead man's egocentric plans for building a new St Petersburg.

The dozen Russian films of both artistic and commercial merit booked by Karlovy Vary played not only to full houses but also to audiences of native Russians residing at the Russian-owned Hotel Imperial and some other deluxe hotels in this spa resort. The expanded Karlovy Vary airport offers two direct flights a day to Moscow via different airlines. There's a Russian-language channel broadcasting news and entertainment most of the day to spa guests. With statistics like these to work with, Karlovy Vary programmers will, of course, continue to invite quality Russian films in the future -- and they are sure to get them, give or take a parallel-running Moscow festival.

No doubt about it -- and with all due praise to Jan Sverak's Oscar-winner Kolya -- Karlovy Vary 33 heralded the revival of Czech cinema and augured well for Slovak production too. Vladimir Michalek's Sekal Has to Die, the official Czech entry in the competition and opening night presentation, marked the director's second time around competing for the Crystal Globe at Karlovy Vary. Last year, his Forgotten Light (1996) was honoured with no less than three citations: Best actor (Boleslav Polívka), the Public's Prize, and the Ecumenical Award. The story of a village priest who refuses to compromise his moral principles, The Forgotten Light was adapted from a novel by Czech priest-poet Jakub Deml that had been published in 1934 but updated to the 1980s under the communist regime.

One of the leading figures in the current revival of Czech cinema, 42-year-old Vladimír Michalek had to wait until the Velvet Revolution (1989) before he could make his mark as an independent documentary filmmaker (The Silence That Hurts, 1990) and creative video artist. His debut feature film, America (1994), based on themes in Kafka's uncompleted novel, was honoured with four "Czech Lion" nominations -- topped two years later with six nominations for Forgotten Light (1996). After his screenplay for Sekal Has to Die received support from the French Ministry of Culture (CNC), Eurimages, and the Czech Ministry of Culture, it was promptly backed by a half-dozen production companies in four countries.

Set in German-occupied Moravia in the critical war year of 1943, Sekal Has to Die is the story of an unscrupulous landowner who makes treacherous use of the imposed "protectorate" status to denounce his neighbours and take over their farms. To defend themselves against the cruel Sekal (Boguslaw Linda), the community engages a fugitive farmer, Jura Baran (Olaf Lubaszenko), to kill the avaricious interloper. The showdown comes when the pair meet in a fight to the death with knives. Polish actor-director Olaf 
Lubaszenko was awarded Best Actor in this genre tale constructed along the lines of the American Western and the Japanese Samurai myth.

Just as entertaining, although short on aesthetic attributes, was the Slovak entry in the competition: Vladimir (Vlado) Balco's Rivers of Babylon, a combination black comedy and political parable that triumphs by taking some obvious potshots at prime minister Vladimír Meiar's tactics in running the country. As was confirmed at the press conference, the production had been stalled several times over the past three years due to "interference from above." But when Rivers of Babylon premiered in Bratislava, shortly before its international bow at Karlovy Vary, the audience turned out in droves during the first week of release.

A veteran director of award-winning shorts, documentaries, and short features, 49-year-old Vlado Balco already had 18 productions to his credit (mostly shorts and documentaries) before he secured the needed backing for his dream project: Rivers of Babylon, a production adapted from Peter Pistánek's recent bestseller that took two years to complete. The challenge is not to be minimized, for the novel features not only a score of colourful characters but also requires a sure hand to stage this biting, stinging, scathing black comedy about life and times "somewhere in the middle of Europe" in the autumn of 1989, on the eve of the Velvet Revolution.

Like Eugene O'Neill drama The Hairy Ape, Balco's Rivers of Babylon is set in a boiler-room, the metaphor assimilating further social significance because it's in the basement of the once luxurious Hotel Ambassador. From the very moment the brutal simpleton Rácz (Andrej Hryc) arrives on the scene, his fortune dramatically changes: a bundle of banknotes falls into his hands, along with a swindler whom he can effectively manipulate. Thereafter, his climb to "big business" and political power is as ruthlessly achieved as it is unscrupulously calculated. For Rácz always finds corrupt partners and conceited foils to bring him a step further along the way to wealth and power.

Of the eight entries in the Czech Films section, An Ambiguous Report about the End of the World by Juraj Jakubisko, a Slovak director based in Prague, impressed with his poetic style of "magic realism" at the Montreal festival last summer. Oskar Reif's The Bed, billed as "the first Czech pornotragedy," was selected for the Critics' Week at Cannes this May. However, the real Czech breakthrough can be gauged by the back-to-back international awards handed out at Bergamo and Rotterdam for Petr Zelenka's inventive Buttoners, directed by the same talent who spoofed the viewing public in the absurd fiction-documentary Happy End (1996). Another standout production was the feature debut by documentary filmmaker Ivan Voynar: The Way through the Bleak Forest, a sociopolitical parable set in an isolated village on the eve of the First World War. And Pavel Marek's Dead Beetle, yet another debut feature, scored with the young crowd as a tragicomedy about first love and the ache of a daydreamer to become somebody without having to commit himself in any way.

Czech documentaries also attracted critical attention. Helena Trestikova's The Sweet Century shared the award for Best Documentary at Karlovy Vary. This moving portrait of seven intelligent women imprisoned for a decade (more, in some cases) under the communist dictatorship does anything but preach. Rather, it focuses on human dignity and the mutual determination of the women to held firm to their ideals and maintain an inner liberation entirely free of hate for their persecutors and the thought of revenge. Thus the title: while looking back on their childhood and reviewing their lives during the prewar era, the women reflect on how "sweet" this century generally has been to them as participants in a cultivated national heritage -despite all.

The International Jury, whose members included Jiri Menzel (Czech Republic), Irakli Kvirikadze (Georgia), Jerzy Skolimowski and Jerzy Stuhr (both from Poland), awarded the Crystal Globe to the French-Canadian entry: Charles Binamé's Le coeur au poing (Streetheart), a poignant tale about a warmhearted but lonely woman who decides to offer her "services" to any passer-by on the street who needs them. For his sensitive approach to a quite unusual theme, Binamé was also awarded Best Director -- an honour he fully deserved.

\section{AWARDS \\ International Jury}

Crystal Globe

Le coeur au poing (Street heart, Canada), Charles Binamé 
Special Prize

Den polnoluniya (Full Moon, Russia), Karen Shakhnazarov

Best Director

Charles Binamé, Le coeur au poing (Streetheart)

Best Actress

Julia Stiles, in Wicked (USA)

Best Actor

Olaf Lubaszenko, in Je treba zabit Sekala (Sekal Has to Die, Czech Republic/Poland/France/Slovakia)

Special Prize for Author Debut

Sandra Goldbacher, The Governess (UK)

Documentary Jury

Best Documentary (ex aequo)

Moment of Impact (USA), Julia Loktev, and Sladke stoleti (The Sweet Century, Czech Republic), Helena

Trestikova

Special Mention

Kisangani Tagebuch (Kisangani Diary, France/Austria), Hubert Sauper, and Golosa (Russ.), Andrej Osipov

Special Prize, Outstanding Contribution to World Cinema

Michael Douglas, Frantisek Vlacil, Saul Zaentz

Life Achievement Prize

Lauren Bacall, Rod Steiger

International Critics (FIPRESCI) Prize

Tic Tac (Sweden), Daniel Alfredson

Special Mention: Den polnoluniya (Full Moon, Russia), Karen Shakhnazarov

Ecumenical Jury

Comedian Harmonists (Germany/Austria), Joseph Vilsmaier

Special Mention: Je treba zabit Sekala (Sekal Has to Die)

Don Quixote Prize, International Film Clubs (FICC)

Tic Tac (Sweden), Daniel Alfredson

Special Mention: The Sugar Factory (Australia), Robert Carter, and Killer (Kazakhstan/France), Darezhan Omirbaev

\section{Audience Prize, Kodak Vision}

The Governess (UK), Sandra Goldbacher

\section{Author Information}

Ron HOLLOWAY (1933-2009) was an American critic, film historian, filmmaker and correspondent who adopted Europe as his home in the early fifties and spent much of his life in Berlin. He was an expert on the study of German cinema and against all odds produced, with his wife Dorothea, the journal German Film, keeping us up-to-date with the work of directors, producers and writers and the showing of German films around the world.

In 2007, Ron Holloway and his wife were awarded the Berlinale Camera Award. Ron also received the Bundesverdienstkreuz (German Cross of Merit), Polish Rings, Cannes Gold Medaille, the American Cinema Foundation Award, the Diploma for Support of Russian Cinema and an honorary award from the German Film Critics' Association. 
Ron was also a valued contributor to Kinema for the past fifteen years. 